\title{
NEW PROMISING EARLY-RIPENING SOYBEAN GLYCINEMAX (L.) MERRIL VARIETIES POIEDYNOK AND KAPRYZ
}

Yakubenko E.V., Zinchenko A.S., Boyko K.Y., Vedmedeva E.V.

Institute of Oilseed Crops of National Academy of Agrarian Sciences, Ukraine

The article presents the experimental results on creating new early-ripening soybean varieties Kapryz and Poiedynok, which are adapted to the arid conditions of Southern Ukraine. The original varieties involved in crosses in the Zapizhska Oblast were evaluated. The breeding achievements are represented by new varieties with high and stable yields, resistant to lodging, drought, adverse environmental conditions and damage inflicted by major pathogens and pests. In to the competitive variety trials 2017-2019, the average yields of Poiedynok and Kapryz were $2.1 \mathrm{t} / \mathrm{ha}$ and $2.4 \mathrm{t} / \mathrm{h}$, respectively, exceeding those of check varieties Vasylkivska and Annushka.

Key words: variety, soybean, performance, early ripening, drought resistance, yield.

Introduction. Breeders from different countries work hard to create early-ripening, droughtresistant, highly-productive and adapted to local climatic conditions varieties. However, not all early-ripening varieties retain this feature when grown in other countries [1]. Varieties created in one zone change their parameters when grown in another, so breeding should be zone-oriented. G.V. Johnson and R.L. Bernard believe that there should be a new variety for every $160 \mathrm{~km}$ in latitude, i.e. 1 degree, [2]. In addition, breeders should to take into account scientific achievements to increase grain yield, drought resistance, cold tolerance, suitability for technical processing, grain quality, etc. [3].

Early-ripening soybean varieties are of particular importance in all regions of Ukraine, as they allow for expansion of the crop area, production of high-quality ripe grain and use of plants in intermediate sowing and replanting. However, soybean is a short-day crop and, accordingly, its anthesis onset depends on the photoperiod [4]. It is known that early ripeness in soybean is determined by two genes that cause phytochrome A dysfunction (their recessive alleles determine the independence of the anthesis onset on the photoperiod), one flowering suppressor [5] and ripeness genes [6,7]. The ripening period after the anthesis onset depend on several important factors: photosynthesis peculiarities and available solar radiation [8]. However, a longer period of ripening also leads to higher yields due to increased numbers of pods, seeds and lateral stems [9, $10]$.

Southern Ukraine requires a special composition of soybean varieties, which is due to sufficient amount of solar radiation, but insufficient, or even critical for the crop, precipitation. Therefore, the earlier flowers and pods form, the more water is spent on the yield formation and, accordingly, the greater the yield is. It is necessary to maintain a sufficiently high attachment of the lowest pod for the variety to be easily harvested and to add stress resistance at the genetic level, for example as an increase in gamma amino-butyric acid concentration [11], or a reduction in the mesophile conductivity [8].

The choice of starting material and creation of new short-season and early-ripening soybean varieties require comprehensive studies of starting material, combinations of features that are desirable in a would-be variety, in parents and selection for these features. A.K. Leshchenko showed that upon hybridization early ripeness dominated or inherited by an intermediate type in the first generation [12]. In cases where the growing period of $F_{1}$ hybrids was intermediate between the parents, both more early-ripening and late-ripening plants were found in subsequent generations.

(C) E.V. Yakubenko, A.S. Zinchenko, K.Y. Boyko, E.V. Vedmedeva. 2021.

ISSN 1026-9959. Селекція і насінництво. 2021. Випуск 119 
Therefore, the selection for several important features and creation of a new variety, adapted to Southern Ukraine, is a very difficult challenge.

The purpose was to create new soybean varieties and combine early ripening, drought resistance and performance in them, which is necessary to obtain soybean yields in Southern Ukraine.

Materials and methods. To create new varieties, soybean accessions from a collection of the Institute of Oil Crops NAAS were taken as starting material. In previous studies, potential donors of valuable traits were identified. The donors were investigated in two-row plots of $9.8 \mathrm{~m}^{2}$ in two replications as per the environmental trial technique. Selected accessions were crossed by S.V. Didorenko et al. modified method [13]. $\mathrm{F}_{1}$ hybrids were propagated, and seeds were harvested from each plant separately. $F_{2}$ hybrids were sown as follows: seeds were sown by twos in the $70 \mathrm{~cm} \mathrm{x} 70$ $\mathrm{cm}$ square-cluster method of planting. Seeds were sown in breeding nurseries: seeds from each plant in a separate plot. Selection was started from $\mathrm{F}_{2}$, and the offspring of the best plants were only sown in the following years. Elite plants were selected in the full ripeness phase by visual assessment of valuable economic traits. In $\mathrm{F}_{4}$ and subsequent generations, constant accessions were transferred to study nurseries as per the full breeding desing, which included breeding nurseries of study years 1 and 2, a control nursery, preliminary and competitive variety trials.

In previous variety trials, several valuable economic characteristics were thoroughly evaluated: ripeness group, yield capacity, plant height, attachment of the lowest pod, resistance to shedding and lodging, resistance to diseases (Ascochyta blight, downy mildew, Septoria brown spot), oil content, protein content, 1000-seed weight, drought resistance, suitability for mechanized harvesting, and seed quality. At the final stage in the competitive variety trials, all morphological characteristics of the new varieties were described, as specified in "CMEA's Expanded Harmonized Classifier and CMEA's International Classifier of the Genus Glycine Willd." [14] and using methods Distinctness, Uniformity and Stability (DUS) testing [15]. Data were statistically processed by analysis of variance, as B.A. Dospekhov described, in Microsoft Excel [16].

Results and discussion. Domestic soybean variety Poiedynok was created by intraspecies hybridization followed by individual selection from the $F_{2}$ hybrid population (Hodson/Dunaika)/Soniachna. The Hodson/Dunaika offspring segregated many times and produced many families with various growing priods and other characteristics. Hodson is a Canadian variety, belongs to the medium-stem type, its plants are tall [17]. Its peculiarities are the increased number of seeds per pod ( $40 \%$ of four-seeded pods) and resistance to many diseases and pests. According to the original description, Hodson has a growing period of 95-115 days, its plants are 87-110 tall, the lowest pod attachment height is $15-17 \mathrm{~cm}$, the 1000 -seed is weight of $32-165 \mathrm{~g}$, the protein content $41-45 \%$, and the oil content $20-22 \%$. Zaporizhzhia is arid, and because of water deficit the variety cannot fully realize its yield potential. Thus, the plant height reached only $71 \mathrm{~cm}$, and the lowest pod attachment height was $7 \mathrm{~cm}$. At that time, with sufficient precipitation, the growing period was extended to 129 days. The results of studying the original varieties involved in the creation of Poiedynok under the Zaporizhzhia conditions are summarized in Table 1.

The second component of the hybrid, variety Dunaika, according to the originator, has a shorter growing period (100-110 days), lower 1000-seed weight (115-128 g), and lower attachment of the lowest pod $(10-13 \mathrm{~cm})$ than Hodson. Observations of Dunaika at the Institute of Oil Crops NAAS also showed it did not fully realize the potential stated by the originator, but Dunaika had a shorter growing period. Therefore, this variety was included in hybridization to create a more drought-resistant and early-ripening starting material. The obtained Hodson/Dunaika offspring differed in the growing period and other properties. Among them, there were plants of $61-95 \mathrm{~cm}$, with lowest pod attachment height of 6.4-17 cm and the growing period of 102 days. However, the pod number per plant was small $-62-53$. This meant a fairly low yield compared to other varieties. At that time, variety Soniachna had been already created at the Institute of Oil Crops; it gave a high yield due to the pod number, which was twice as much as that in the Hodson/Dunaika offspring and other collection accessions. 
The original varieties studied at the Institute of Oil Crops NAAS, 2009-2011

Table 1

\begin{tabular}{ccccccc}
\hline & \multicolumn{5}{c}{ Variety } \\
\cline { 2 - 6 } Feature & Diona & Bystrytsia & $\begin{array}{c}\text { Hodson / } \\
\text { Dunaika }\end{array}$ & Dunaika & Hodson & Soniachna \\
\hline $\begin{array}{c}\text { Height, cm } \\
\text { Node number } \\
\text { Lowest pod }\end{array}$ & $37.4 \pm 4.6$ & $75.0 \pm 4.3$ & $61-95$ & $70.1 \pm 2.6$ & $71 \pm 2.8$ & $80.4 \pm 1.3$ \\
attachment height, & $5.2 \pm 0.9$ & $3.6 \pm 0.9$ & $2-3$ & $3.5 \pm 0.7$ & $4.7 \pm 0.9$ & $5.4 \pm 0.8$ \\
$\begin{array}{c}\text { cm } \\
\text { Pod number }\end{array}$ & $74.6 \pm 5.9$ & $84.4 \pm 12.2$ & $53-62$ & $55.3 \pm 13.3$ & $72.3 \pm 11.0$ & $102.8 \pm 17.4$ \\
$\begin{array}{c}\text { 1000-seed weight, } \\
\text { g }\end{array}$ & $128.8 \pm 3.3$ & $132 \pm 5.8$ & $115-128$ & $115.4 \pm 5.1$ & $141.0 \pm 4.7$ & $129.9 \pm 6.1$ \\
$\begin{array}{c}\text { Growing period, } \\
\text { days }\end{array}$ & $89 \pm 0.9$ & $97 \pm 1.4$ & $100-108$ & $95.0 \pm 0.7$ & $119.0 \pm 2.8$ & $114.8 \pm 1.2$ \\
$\begin{array}{c}\text { Yield, t/ha } \\
\text { thein content in }\end{array}$ & $11.9 \pm 3.0$ & $10.7 \pm 2.4$ & $10.2-17.5$ & $10.3 \pm 2.9$ & $12.2 \pm 2.7$ & $19.7 \pm 2.2$ \\
$\begin{array}{c}\text { seeds, \% } \\
\text { Oil content in } \\
\text { seeds, \% }\end{array}$ & $23.7 \pm 3.8$ & $39.0 \pm 0.7$ & $25-35$ & $29.5 \pm 2.5$ & $38.7 \pm 2.9$ & $25.7 \pm 3.5$ \\
\hline
\end{tabular}

But Soniachna had the maximum height of the lowest pod attachment of $9.6 \mathrm{~cm}$ and the average vegetation duration of 114 days. To create a high-yielding, more early-ripening variety with an adequate height of the lowest pod attachment, the early-ripening family from the Hodson/Dunaika cross (vegetation period of 102 days) was crossed with Soniachna.

From subsequent generations, starting from $\mathrm{F}_{3}$, individual selections were carried out, and constant families were tested in breeding nurseries. As a result of the selections, the best breeding accession was chosen, which was called Poiedynok and submitted for qualification examination in 2020. The results of a three-year variety trial at the Institute of Oil Crops NAAS are summarized in Table 2.

Table 2

Yields of soybean varieties Poiedynok and Kapryz in the competitive variety trials, 2017-2019

\begin{tabular}{|c|c|c|c|c|c|c|c|}
\hline \multirow[b]{2}{*}{ Variety } & \multirow{2}{*}{$\begin{array}{l}\text { Growing } \\
\text { period, } \\
\text { days }\end{array}$} & \multirow{2}{*}{$\begin{array}{l}\text { Yield, } \\
\text { t/ha }\end{array}$} & \multicolumn{2}{|c|}{ Height, $\mathrm{cm}$} & \multirow{2}{*}{$\begin{array}{l}\text { 1000-seed } \\
\text { weight, g }\end{array}$} & \multicolumn{2}{|c|}{ Content, \% } \\
\hline & & & plant & $\begin{array}{l}\text { lowest pod } \\
\text { attachment }\end{array}$ & & oil & protein \\
\hline Kapryz & $90.0 \pm 0.71$ & $2.1 \pm 0.27$ & $72.3 \pm 5.49$ & $13.6 \pm 0.92$ & $139.5 \pm 9.65$ & $21.6 \pm 0.67$ & $38.3 \pm 0.39$ \\
\hline $\begin{array}{l}\text { Annushka, } \\
\text { check } \\
\text { variety }\end{array}$ & $95.7 \pm 2.33$ & $1.6 \pm 0.26$ & $72.0 \pm 3.61$ & $6.0 \pm 0.58$ & $134.3 \pm 3.48$ & $19.7 \pm 0.88$ & $38.7 \pm 0.88$ \\
\hline Poiedynok & $100.7 \pm 2.33$ & $2.3 \pm 0.15$ & $80.0 \pm 2.89$ & $13.7 \pm 0.88$ & $148.3 \pm 9.74$ & $21.0 \pm 0.58$ & $38.0 \pm 0.58$ \\
\hline $\begin{array}{c}\text { Vasylkivska, } \\
\text { check } \\
\text { variety }\end{array}$ & $115.7 \pm 0.67$ & $1.67 \pm 0.19$ & $65 \pm 2.89 \pm$ & $7 \pm 0.58$ & $130.3 \pm 7.54$ & $20 \pm 0.58$ & $35.7 \pm 0.33$ \\
\hline
\end{tabular}

The new variety, Poiedynok, had good economic indicators in the steppe of Ukraine. The average yield for three years was $2.3 \mathrm{t} / \mathrm{ha}, 1000$-seed weight $-148.3 \mathrm{~g}$, protein content $-38.0 \%$, oil content $-21.0 \%$, and the growing period - 100 days. At the same time, the national check variety of the mid-early group, Vasylkivska, had a growing period of 115.7 days, 1000- seed weight of 148.3 $\mathrm{g}$, average yield of $1.67 \mathrm{t} / \mathrm{ha}$, and the height of the lowest pod attachment of only $7 \mathrm{~cm}$ (which is 
much lower than in the new variety, as it was $13.78 \mathrm{~cm}$ in Poiedynok). The protein content in Poiedynok was significantly higher than that in Vasylkivska, and the oil content did not significantly differ.

Poiedynok is characterized by a complete (determinant) type of growth; its bush is semicompressed. The stem is erect; the main stem and mainly up to 2-3 lateral branches form the top. The plant does not lodge; branches do not fracture at the bottom. There is no anthocyanin pigmentation of cotyledons. The stem is $70-80 \mathrm{~cm}$ tall. The stem pubescence is short, thick, white. When the plant is ripe, the stem turns gray. The leaf is compound, ternate, and moderate in color, with stipules. The predominant leaf shape is oval, of medium size. When the plant is ripe, its leaves fall off. The flower is medium-sized, white, located in the leaf axil. The plant produces 15-25 flowers. The pod pubescence is light-brown, medium, slightly curved, and contains 3-4 seeds. Pods are evenly distributed on the plant, closely spaced at the top or at the bottom. Seeds are yellow, oval, and medium-sized. The hilum is straight, its color is the same as the testa color. The variety is resistant to lodging and pod shattering, withstands high temperatures during the budding and seed filling stages. The drought resistance of Poiedynok is above medium. As to the protein and oil contents, this variety can be universally used - both for oil and food protein (the protein content is $38 \%$; the oil content is $21 \%$ ). The variety is highly adapted to the local climate; its physiological indicators are manifested primarily as an intensive accumulation of biomass, photosynthetic activity and a large leaf area. Poiedynok is tolerant and resistant to major fungal diseases, highly resistant to lodging, shedding and drought.

Breeding in arid conditions requires a large amount of early-ripening starting material. For this purpose, varieties Diona and Bystrytsia 2 were crossed. The male component, Diona, was very early-ripening in the Zaporizka Oblast - 89-95 days. The height of the lowest pod attachment is described as 11-12 cm, but under our conditions it was only $5.2 \mathrm{~cm}$. Bystrytsia 2 had a longer growing period of 97 days (the originator specifies it as 100-105 days), and the observed in the steppe of Ukraine height of the lowest pod attachment was greater than in the description (11-12 $\mathrm{cm})$.

In subsequent generations, the best families, with the highest yields and shortest vegetation, were selected from the offspring and grown in the breeding nurseries. The best family (according to the results of the competitive variety trials) was submitted as variety Kapryz. This variety has a very short growing period of 90 days, gives a high (for such a sort growing period) yield of $2.1 \mathrm{t} / \mathrm{ha}$, which differed significantly from the check variety for this ripeness group, Annushka. In addition, the height of the lowest pod attachment is $13.6 \mathrm{~cm}$ in this variety, which is higher than in the check varieties. The oil content of seeds is significantly higher than that in the check varieties, with a similar protein content.

Kapryz has green cotyledons and mesocotyles in young plants. The type of growth is determinant; the bush is semi-compressed. The stem is erect. The plant height is $55-75 \mathrm{~cm}$. The stem pubescence is light. The leaf is medium-sized, oval, of moderate color. When the plant is ripe, its leaves fall off. The flower is violet, medium-sized. The pod is medium, slightly curved, light in color, and contains 3-4 seeds. Seeds are medium, oval, and yellow. The hilum is yellow. The 1000seed weight is $125-160 \mathrm{~g}$. The protein content is $32-36 \%$; the lipid content is $20-24 \%$. The seed yield is $1.8-2.3 \mathrm{t} / \mathrm{ha}$. The variety ripens very early (the "germination - economic value" period is 90 days).

Kapryz and Poiedynok were eveluated for disease susceptibility and drought resistance in the field. It was revealed that the new varieties were better adapted to arid conditions due to early ripening, as they begin flowering and, accordingly, seed formation earlier than the check varieties and give higher yields.

The study of the starting material of the new varieties fully confirmed IV Seferov et al.'s conclusions [1] on the differences in expression of important characteristics of soybean varieties when grown in different conditions. Namely, it turned out that the potentially very high-yielding varieties, Hodson and Diona, could not give high yields, 1000-seed weight and form large numbers of pods in the steppe of Ukraine. However, they were good as donors of these qualities in the new 
varieties, Poiedynok and Kapryz. Successful breeding of early-ripening soybean varieties, adapted for the arid climate of Southern Ukraine, was ensured primarily by selection of offspring under the extreme conditions of water deficit in the southern steppe of Ukraine and involvement of earlyripening varieties, with high potential to produce lateral stems. However, the yields are still quite low in the Zaporiska Oblast, and it is very difficult to increase soybean yields in these conditions. Yields are limited by moisture, which in most years is not sufficient for soybean. Nevertheless, breeding under drought made it possible to create such varieties, which, with at least a little more moisture, give high yields. Thus, the qualification examination [18] of Kapryz for valuable economic characteristics in 12 sites revealed that the average yield of from this variety was $1.8 \mathrm{t} / \mathrm{ha}$ in the steppe, $2.9 \mathrm{t} / \mathrm{ha}$ in the forest-steppe and $2.8 \mathrm{t} / \mathrm{ha}$ in the woodlands in 2019. The highest yield was recorded at Dnipro Regional State Center for Examination of Plant Varieties - 3.5 t/ha. The growing period ranged from 86 days in the steppe to 115 in the woodlands. The protein content in all test sites exceeded $30 \%$, with the average oil content of $24.9 \%$ in the steppe. These results indicate the high potential of a particular variety and effectiveness of the breeding under arid conditions.

Conclusions. The new early-ripening soybean varieties, Poiedynok and Kapryz, have been created; their vegetation periods are 100 days and 95 days, respectively; the potential yields amount to $3.5 \mathrm{t} / \mathrm{ha}$, with the average yield of $2.3 \mathrm{t} / \mathrm{ha}$ from Poiedynok and $2.1 \mathrm{t} / \mathrm{ha}$ from Kapryz. The varieties meet the process specifications in terms of the plant height and the height of the lowest pod attachment, even ripening, resistance to lodging and pod shattering. They are tolerant to major fungal diseases and drought. The effectiveness of selection starting from $\mathrm{F}_{3}$ offspring was confirmed when crossing soybean varieties was oriented for vegetation period and performance under the natural arid conditions of the Zaporizka Oblast.

\section{Список використаних джерел}

1. Сеферова І.В., Місюрина Т.В., Никишкіна М.А. Еколого-географічна оцінка біологічного потенціалу скоростиглих сортів та опівнічювання сої. Сільськогосподарська біологія. Сер. Біологія рослин. 2007. № 5. С. 42-47.

2. Johnson H.W., Bernard R.L. Soybean genetics and breeding. Soybean. Advances in Agronomy. 1967. № 14. P. 149-221. DOI: 10.1016/50065-2113(08)60438-1.

3. Толоконников В.В., Кошкарова Т.С., Иленева С.В., Канцер Г.П. Селекция скороспелых сортов сои для русловий орошения. Междужнародный научно-исследовательский журнал. 2016. Вып. 3 (45). Часть 3. C. 123-124. DOI:10.18454/IRJ.2016.45.037.

4. Tripathi R., Agrawal N., Kumawat G., Gupta S., Varghese P., Ratnaparkhe M.B., Bhatia V.S., Maranna S., Satpute G.K., Chand S., Jain M. QTL mapping for long juvenile trait in soybean accession AGS 25 identifies association between a functional allele of FT2a and delayed flowering. Euphytica. 2021. V. 217, № 3. P. 12.

5. Zhu J.H., Takeshima R., Harigai K., Xu M.L., Kong F.J., Liu B.H., Kanazawa A., Yamada T., Abe J. Loss of Function of the E1-Like-b Gene Associates With Early Flowering Under LongDay Conditions in Soybean. Frontiers in Plant Science. 2019. V. 9. P. 13.

6. Langewisch T., Lenis J., Jiang G.L., Wang D.C., Pantalone V., Bilyeu K. The development and use of a molecular model for soybean maturity groups. Bmc Plant Biology. 2017. V. 17. P. 13.

7. Gupta S., Bhatia V.S., Kumawat G., Thakur D., Singh G., Tripathi R., Satpute G., Devadas R., Husain S.M., Chand S. Genetic analyses for deciphering the status and role of photoperiodic and maturity genes in major Indian soybean cultivars. Journal of Genetics. 2017. V. 96. № 1. P. 147-154.

8. Blessing C.H., Mariette A., Kaloki P., Bramley H. Profligate and conservative: water use strategies in grain legumes. Journal of Experimental Botany. 2018. V. 69. № 3. P. 349-369.

9. Kantolic A.G., Peralta G.E., Slafer G.A. Seed number responses to extended photoperiod and shading during reproductive stages in indeterminate soybean. European Journal of Agronomy. 2013. V. 51. P. 91-100. 
10. Saryoko A., Homma K., Lubis I., Shiraiwa T. Plant development and yield components under a tropical environment in soybean cultivars with temperate and tropical origins. Plant Production Science. 2017. V. 20. № 4. P. 375-383.

11. Morrison M.J., Fregeau-Reid J.A., Cober E.R. Genotype and environment influence gamma aminobutyric acid concentration in short-season soybean. Canadian Journal of Plant Science. 2012. V. 92. № 6. P. 1093-1100.

12. Лещенко А.К. Культура сої. Київ: Наукова думка, 1978. 236 с.

13. Дідоренко С.В., Корягін Ю.Г., Булатова К.М. Патент № 31427 на винахід «Спосіб гібридизації сої. Казахський НИИ землеробства та рослинництва, заява № 2011/0010.1. 2016.

14. Широкий унифицированный классификатор СЭВ и международный классификатор СЭВ рода Glycine WILLD. Л.: ВИР, 1981.

15. Методика проведення експертизи сортів на відмінність, однорідність та стабільність (ВОС). Зернобобові культури. Київ, 2000.

16. ДоспЕхов Б.А. Методика полевого опыта (с основами статистической обработки результатов опытов). 5-е изд., доп. и перераб. Москва: Агропромиздат, 1985. 351 с.

17. Зеленцов С., Кочегура А. Современное состояние систематики культурной сои Glycine max (L.) Merrill. Масличные культуры. 2006. № 1 (134).

18. Методика проведення кваліфікаційної експертизи сортів рослин на придатність до поширення в Україні. Загальна частина. 4-те вид., випр. і доп. Вінниця. 2017. 119 с.

\section{References}

1. Seferova IV, Misyurina TV, Nikishkina MA. Ecological and geographical assessment of the biological potential of early ripening varieties and soybean verification. Sel'skokhozyaystvennaya biologiya. Ser. Biologiya rasteniy. 2007; 5: 42-47.

2. Johnson HW, Bernard RL. Soybean genetics and breeding. Soybean. Advances in Agronomy. 1970; 14: 149-221. DOI: 10.1016/50065-2113(08)60438-1.

3. Tolokonnikov VV, Koshkarova TS, Ileneva SV, Kantser GP. Selection of early maturing soybean cultivars for conditions of irrigation. Mizhnarodnyy naukovo-doslidnyy zhurnal International scientific research journal. 2016; 3(45): 123-124. DOI: 10.18454/IRJ.2016.45.037.

3. Butovecz ES. Evaluation of soybean cultivars in environmental test. Sil's'ke hospodarstvo. 2011; 6: 38-39.

4. Tripathi R, Agrawal N, Kumawat G, Gupta S, Varghese P, Ratnaparkhe MB, Bhatia VS, Maranna S, Satpute GK, Chand S, Jain M. QTL mapping for long juvenile trait in soybean accession AGS 25 identifies association between a functional allele of FT2a and delayed flowering. Euphytica. 2021; 217(3): 12.

5. Zhu JH, Takeshima R, Harigai K, Xu ML, Kong FJ, Liu BH, Kanazawa A, Yamada T, Abe J. Loss of Function of the E1-Like-b Gene Associates With Early Flowering Under Long-Day Conditions in Soybean. Frontiers in Plant Science. 2019; 9: 13.

6. Langewisch T, Lenis J, Jiang GL, Wang DC, Pantalone V, Bilyeu K. The development and use of a molecular model for soybean maturity groups. Bmc Plant Biology. 2017; 17: 13.

7. Gupta S, Bhatia VS, Kumawat G, Thakur D, Singh G, Tripathi R, Satpute G, Devadas R, Husain SM, Chand S. Genetic analyses for deciphering the status and role of photoperiodic and maturity genes in major Indian soybean cultivars. Journal of Genetics. 2017; 96(1): 147-154.

8. Blessing CH, Mariette A, Kaloki P, Bramley H. Profligate and conservative: water use strategies in grain legumes. Journal of Experimental Botany. 2018; 69(3): 349-369.

9. Kantolic AG, Peralta GE, Slafer GA. Seed number responses to extended photoperiod and shading during reproductive stages in indeterminate soybean. European Journal of Agronomy. 2013; 51: 91-100. 
10. Saryoko A, Homma K, Lubis I, Shiraiwa T. Plant development and yield components under a tropical environment in soybean cultivars with temperate and tropical origins. Plant Production Science. 2017; 20(4): 375-383.

11. Morrison MJ, Fregeau-Reid JA, Cober ER. Genotype and environment influence gamma aminobutyric acid concentration in short-season soybean. Canadian Journal of Plant Science. 2012; 92(6): 1093-1100.

12. Leshchenko AK. Soybean culture. Naukova dumka [Scientific thought]. Kiev. 1978; 236.

13. Didorenko SV, Karyagin YG, Bulatova KM. Method of soybean hybridization. Patent 31427 , Kazakh scientific research Institute of agriculture and plant growing. 2016.

14. Wide unified CMEA classifier and the international CMEA classifier of the genus Glycine Willd. Leningrad: VIR, 1981; $1990 \mathrm{p}$.

15. Methodology for conducting an examination of varieties for performance, uniformity and stability (VOS). Grain beans of culture. Kyiv, 2000.

16. Dospekhov BA. Methodology of field experience with the basics of statistical process. $5^{\text {th }}$ ed. red. Moscow: Ahropromizdat, 1985. $351 \mathrm{p}$.

17. Zelentsov S, Kochegura A. The current state taxonomy of cultivated soybeans Glycine max (L.) Merrill. Maslichnye kultury. 2006; 1: 134.

18. Methods of qualification examination of plant varieties for suitability for distribution in Ukraine. The general part. 4th ed., Corr. and ext.Vinnitsa. 2017. 119 p.

\section{НОВI ПЕРСПЕКТИВНI РАННЬОСТИГЛI СОРТИ СОÏ GLYCINE MAX (L.) MERRIL ПОЕДИНОК ТА КАПРИЗ}

Якубенко О.В., Зінченко О.С., Бойко К.Я., Ведмедєва К.В.

Інститут олійних культур НААН, Україна

Мета дослідження - створення нових сортів сої та поєднання у них ранньостиглості, посухостійкості та продуктивності, необхідних для формування врожаю сої на півдні України.

Матеріали і методи дослідження. Для створення нових сортів вихідним матеріалом були зразки колекції сої Інституту олійних культур НААН. На основі попередніх досліджень було виділено потенційні донори цінних ознак. Вивчення донорів відбувалось на дворядкових ділянках площею $9,8 \quad \mathrm{~m}^{2}$ у двох повтореннях екологічного сортовипробування. Гібриди $\mathrm{F}_{1}$ розмножували і збирали насіння з кожної рослини окремо. Гібриди $\mathrm{F}_{2}$ сіяли по дві насінини квадратно-гніздовим способом за схемою 70 х 70 см.

Обговорення результатів. Отримані результати вивчення вихідного матеріалу сортів повністю підтверджують висновки Сеферова І.В. з співавторами про відмінність рівня прояву важливих ознак сортів сої при вирощуванні в інших умовах. А саме виявилось, що потенційно дуже врожайні сорти Ходсон і Діона не змогли в умовах Степу України виявити високу врожайність, масу 1000 насінин і сформувати велику кількість бобів. Однак використання їх як донорів цих якостей виявило у нових сортах Поєдинок та Каприз високий потенціал врожаю. Успіх в селекції ранньостиглих сортів сої пристосованих до вирощування у посушливому кліматі Півдня України забезпечили перш за все добір потомства в екстремальних умовах вологозабезпеченості півдня степу України та залучення сортів 3 ознаками ранньостиглості та високого потенціалу формування бічних стебел.

Висновки. Створено нові ранньостиглі сорти сої Поєдинок та Каприз, вегетаційний період становить 100 та 95 діб відповідно з високим потенціалом врожайності до 3,5 т/га та середнім показником врожайності 2,3 т/га сорту Поєдинок та 2,1 т/га сорту Каприз. Сорти відповідають технологічним умовам за висотою рослин і прикріпленням нижнього бобу, 
дружності дозрівання, стійкості до вилягання і розтріскуваності бобів, $є$ толерантними до основних грибних хвороб та посухи.

Ключові слова: сорт, соя, продуктивність, ранньостиглість, посухостійкість, урожайність.

\section{НОВЫЕ ПЕРСПЕКТИВНЫЕ И СКОРОСПЕЛЫЕ СОРТА СОИ GLYCINE MAX(L.) MERRIL ПОЕДИНОК И КАПРИЗ}

Якубенко Е.В., Зинченко А.С., Бойко К.Я., Ведмедева Е.В.

Институт масличных культур НААН, Украина

Цель исследований - создание новых сортов сои и сочетание в них: раннеспелости, засухоустойчивости и продуктивности, необходимых для формирования урожая сои на юге Украины.

Материалы и методы. Для создания новых сортов использована коллекция сои Института масличных культур НААН. На основе предыдущих исследований было выделено потенциальные доноры ценных признаков. Изучение доноров происходило на двурядных участках площадью 9,8 м² в двух повторениях экологического сортоиспытания. Гибриды $\mathrm{F}_{1}$ размножали и собирали семена с каждого растения отдельно. Гибриды $\mathrm{F}_{2}$ сеяли по два семени квадратно-гнездовым способом по схеме 70 х $70 \mathrm{~cm}$.

Обсуждение результатов. Результат наших исследований исходного материала сортов полностью подтверждают выводы Сеферова И.В о различии уровня проявления важных признаков сортов сои при выращивании в других условиях. Оказалось, что потенциально урожайные сорта Ходсон и Диона не смогли в данных условиях проявить высокий потенциал, набрать массу и сформировать большое количество бобов. Однако использование их в качестве доноров, выявило в новых сортах Каприз и Поединок высокий потенциал урожая. Успех в селекции скороспелых сортов сои приспособленных к выращиванию в засушливом климате Украины обеспечили: отбор потомков в экстремальных условиях юга Украины, привлечение сортов с признаками раннеспелости и высокого потенциала формирования боковых стеблей.

Выводы. Созданы новые скороспелые сорта сои Поединок и Каприз, вегетационный период составляет 100 и 95 суток соответственно. Потенциал урожайности до 3,5 т/га и средним показателем урожайности 2,3 т/га сорта Поединок и 2,1 т/га сорта Каприз. Сорта соответствуют технологическим условиям по высоте растений и высоте прикреплению нижнего боба, дружественности созревания, устойчивы к полеганию и растрескиваемости бобов, обладают толерантностью к основным грибным болезням и засухе.

Ключевые слова: сорт, соя, продуктивность, скороспелость, засухоустойчивость, урожайность.

\section{NEW PROMISING EARLY-RIPENING SOYBEAN GLYCINEMAX(L.) MERRIL VARIETIES POIEDYNOK AND KAPRYZ}

Yakubenko E.V., Zinchenko A.S., Boyko K.Y., Vedmedeva E.V.

Institute of Oilseed Crops of National Academy of Agrarian Sciences, Ukraine

Purpose and objectives. To create new soybean varieties and combine early ripening, drought resistance and performance in them, which is necessary to obtain soybean yields in Southern Ukraine.

Materials and methods. To create new varieties, the soybean collection the Institute of Oil Crops NAAS was used. The potential donors of valuable traits were identified in previous studies. The 
donors were investigated in two-row plots of $9.8 \mathrm{~m}^{2}$ in two replications as per the environmental trial technique. $F_{1}$ hybrids were propagated, and seeds were harvested from each plant separately. $F_{2}$ hybrids were sown as follows: seeds were sown by twos in the $70 \mathrm{~cm} \times 70 \mathrm{~cm}$ square-cluster method of planting.

Results and discussion. Our study of the starting material of the new varieties fully confirmed IV Seferov et al.'s conclusions on the differences in expression of important characteristics of soybean varieties when grown in different conditions. It turned out that the potentially very highyielding varieties, Hodson and Diona, could not fulfill their high potentials, gain weight and form large numbers of pods. However, they were good as donors of high yield in the new varieties, Poiedynok and Kapryz. Successful breeding of early-ripening soybean varieties, adapted for the arid climate of Southern Ukraine, was ensured by selection of offspring under the extreme conditions of water deficit in Southern Ukraine and involvement of early-ripening varieties, with high potential to produce lateral stems

Conclusions. The new early-ripening soybean varieties, Poiedynok and Kapryz, have been created; their vegetation periods are 100 days and 95 days, respectively; the potential yields amount to $3.5 \mathrm{t} / \mathrm{ha}$, with the average yield of $2.3 \mathrm{t} / \mathrm{ha}$ from Poiedynok and $2.1 \mathrm{t} / \mathrm{ha}$ from Kapryz. The varieties meet the process specifications in terms of the plant height and the height of the lowest pod attachment, even ripening, resistance to lodging and pod shattering. They are tolerant to major fungal diseases and drought.

Key words: variety, soybean, performance, early ripening, drought resistance, yield. 